\title{
The systematic position of Cubanthus and other shrubby endemic species of Euphorbia (Euphorbiaceae) in Cuba
}

\author{
by \\ Victor W. Steinmann ${ }^{1}$, Benjamin van Ee ${ }^{2}$, Paul E. Berry ${ }^{3} \&$ Jorge Gutiérrez $^{4}$ \\ ${ }^{1}$ Instituto de Ecología, A.C., Centro Regional del Bajío, Av. Lázaro Cárdenas 253, A.P. 386, 61600 Pátzcuaro, Michoacán, Mexico \\ ${ }^{2}$ University of Wisconsin, Botany Department, 430 Lincoln Drive, Madison, WI 53706, USA \\ Current address: Department of Botany MRC-166, Smithsonian Institution, P. O. Box 37012 Washington, DC 20013-7012, USA \\ ${ }^{3}$ University of Michigan Herbarium, 3600 Varsity Drive, Ann Arbor, MI 48108-2287, USA \\ ${ }^{4}$ Jardín Botánico Nacional, Carretera del Rocío Km 3ํㅡㄹ, Calabazar, 19230 Habana, Cuba
}

\begin{abstract}
Steinmann, V.W., Van Ee, B., Berry, P.E. \& Gutiérrez, J. 2007. The systematic position of Cubanthus and other shrubby endemic species of Euphorbia (Euphorbiaceae) in Cuba. Anales Jard. Bot. Madrid 64(2): 123-133.

Cubanthus (Euphorbiaceae) has traditionally been recognized as a small genus of three similar species restricted to Cuba and Hispaniola. In this study we used DNA sequence data from the nuclear ITS and chloroplast $n d h F$ gene regions to investigate its systematic position and the position of four other shrubby Euphorbia species endemic to Cuba: E. cubensis, E. helenae, E. munizii, and $E$. podocarpifolia. The results demonstrate that all of these taxa belong to a well-supported Antillean clade nested within Euphorbia that also includes E. punicea and E. gymnonota. For that reason, we treat Cubanthus as a section of Euphorbia instead of a separate genus. Euphorbia sect. Adenorima is relegated to a synonym of sect. Cubanthus. New names are proposed for Cubanthus brittonii and Cubanthus linearifolius (Euphorbia millspaughii and E. scutiformis, respectively), and a new combination is made for Cubanthus umbelliformis (Euphorbia umbelliformis). Section Cubanthus belongs to clade C of Euphorbia and is part of a New World assemblage that includes members of sections Euphorbiastrum, Pteroneurae, Portulacastrum, Stachydium, and the former genus Pedilanthus. Based on both the molecular results and morphological differences, two subsections are proposed: subsect. Cubanthus and subsect. Moa. The molecular phylogeny supports the hypothesis that section Cubanthus radiated entirely within the Antilles and the nearby Bahamian archipelago.
\end{abstract}

Keywords: Antilles, Cuba, Cubanthus, Euphorbia, molecular phylogeny.

Cubanthus (Boiss.) Millsp. (Euphorbiaceae) has in recent times been considered a small genus of three

\section{Resumen:}

Steinmann, V.W., Van Ee, B., Berry, P.E. \& Gutiérrez, J. 2007. La posición sistemática de Cubanthus y otras especies arbustivas endémicas de Euphorbia (Euphorbiaceae) en Cuba. Anales Jard. Bot. Madrid 64(2): 123-133 (en inglés).

Cubanthus (Euphorbiaceae) ha sido tradicionalmente reconocido como un género de tres especies muy similares entre sí y endémicas de las islas de Cuba y La Española. En este estudio se emplearon datos de secuencias de ADN tanto nuclear (ITS) como del cloroplasto (ndhF) para investigar la posición sistemática de Cubanthus y de cuatro especies arbustivas de Euphorbia endémicas de Cuba: E. cubensis, E. helenae, E. munizii, y E. podocarpifolia. Los resultados muestran que todas las especies analizadas pertenecen a un clado Antillano anidado en Euphorbia, al cual también pertenecen E. punicea y E. gymnonota. Por tal razón, tratamos a Cubanthus como una sección de Euphorbia en lugar de un género distinto. Euphorbia sección Adenorima se relega como sinónimo de la sección Cubanthus. Se proponen nuevos nombres para Cubanthus brittonii y C. linearifolius (Euphorbia millspaughii y E. scutiformis, respectivamente) y una nueva combinación para Cubanthus umbelliformis (Euphorbia umbelliformis). La sección Cubanthus pertenece al clado $C$ de Euphorbia y es parte de un grupo del Nuevo Mundo que incluye miembros de las secciones Euphorbiastrum, Pteroneurae, Portulacastrum, Stachydium y del anteriormente reconocido género Pedilanthus. Basado en los resultados moleculares y las diferencias morfológicas, se proponen dos subsecciones: subsección Cubanthus y subsección Moa. La filogenia molecular sustenta la hipótesis de que la sección Cubanthus surgió y se diversificó en Las Antillas y el Archipiélago de Las Bahamas.

Palabras clave: Antillas, Cuba, Cubanthus, Euphorbia, filogenia molecular.

closely related species: Cubanthus brittonii Millsp., C. linearifolius (Griseb.) Millsp., and C. umbelliformis 
Urb. \& Ekman (Liogier, 1953; Webster, 1994). All three occur on the Caribbean island of Cuba, and C. umbelliformis is also found on Hispaniola. The species are infrequent and rarely collected, and the group needs a more detailed systematic study to determine if the species distinctions are clear and should be upheld. According to Webster's 1994 classification, the genus belongs to tribe Euphorbieae subtribe Euphorbiinae, within the subfamily Euphorbioideae. Like all other members of subtribe Euphorbiinae, Cubanthus has specialized pseudanthial inflorescences (cyathia) composed of a gland-bearing involucre enclosing a single, central pistillate flower and numerous staminate flowers.

The species of Cubanthus are soft-wooded shrubs or small trees with white latex and spirally arranged stem leaves clustered towards the branch tips. The cyathia occur in clusters of dichotomously branched cymes at the ends of the stems. The group is distinguished from other members of Euphorbiinae by the possession of cyathia with a single shield-shaped gland that is situated on the outer wall of the involucre (Fig. 1a). This is in contrast to the typical condition in Euphorbiinae, in which there are usually 4 or 5 involucral glands positioned along the rim of the involucre. One more interesting feature of Cubanthus is the presence of a well-developed calyx-like structure at the base of the female flower (Fig. 1b). Members of subtribe Euphorbiinae generally possess pistillate flowers that lack a perianth. As mentioned by Steinmann and Porter (2002), it is still uncertain whether these calyx-like structures, which occur in very few species in the subtribe, represent a true perianth, or are simply perianth-like lobes at the end of the gynophore.

Cubanthus was first proposed as a section of the genus Pedilanthus Neck. ex Poit. (Pedilanthus sect. Cubanthus Boiss., 1862), but later Millspaugh (1913) pointed out significant differences between these two groups and elevated Cubanthus to generic status. In his revision of Pedilanthus, Dressler (1958) concurred with Millspaugh's judgment, and since then Cubanthus has been considered a distinct genus. However, Webster (1994) mentioned that Cubantbus is quite similar to Euphorbia sect. Adenorima (Raf.) G.L. Webster and that it should perhaps be included within that group.

Recent molecular studies have demonstrated that the genera traditionally treated in subtribe Euphorbiinae, such as Chamaesyce, Monadenium, Synadenium, Pedilanthus, and Poinsettia, are all nested within a broadly paraphyletic Euphorbia (Steinmann and Porter, 2002; Wurdack \& al., 2005; Bruyns \& al.,
2006). Cubanthus was not included in the Steinmann and Porter study, but C. umbelliformis was sampled by Wurdack \& al. (2005), where it emerged as sister to Euphorbia gymnonota Urb. Because the Wurdack \& al. (2005) analysis included only 11 of the nearly 2000 species of Euphorbiinae, we undertook this study to include a much broader molecular analysis of the subtribe, with the purpose of better assessing the systematic position of Cubanthus, as well as several other previously unsampled species of Euphorbia that are endemic to Cuba.

\section{Materials and methods}

Cubanthus umbelliformis, Euphorbia cubensis Boiss., E. helenae Urb., E. munizii Borhidi, and E. podocarpifolia Urb. were sequenced for the nrDNA internal transcribed spacer (ITS) region and the cpDNA coding region $n d b F$. Euphorbia gymnonota was newly sequenced for $n d b F$, since it had previously been sequenced only for ITS. Amplification and sequencing protocols followed Steinmann \& Porter (2002). The newly generated sequences were added to those originally generated by Steinmann \& Porter (2002), and available from GenBank, for a combined ITS and $n d b F$ data matrix of 105 taxa. Once it was confirmed that these taxa were all embedded within clade C of Steinmann \& Porter (2002) and Bruyns \& al. (2006), the taxa from clades A, B, and D were pared down to four to six each, for a total of 47 taxa, which includes two outgroups, 24 members of clade $\mathrm{C}$ for which Steinmann and Porter obtained sequences of both ITS and $n d b F$, E. gymnonota, and the five species newly sampled in this work (see Fig. 2). The taxon referred to in Steinmann and Porter (2002) as Euphorbia elata is now considered to be a synonym of E. sinclairiana Benth. (Bernal \& al., 2006), so this name is used in place of E. elata in Fig. 2.

Maximum parsimony (MP) and maximum likelihood (ML) analyses were conducted on the combined data matrix using PAUP* 4.0b10 (Swofford, 2002). Separate ITS and $n d h F$ analyses were also conducted. Neoguillauminia cleopatra and Anthostema madagascariense were designated as outgroup taxa following the results of Steinmann \& Porter (2002). Heuristic MP searches were first performed using simple stepwise taxon addition, tree bisection-reconnection (TBR), and without limiting the maximum number of trees saved. This was followed by a search of the combined data set aimed to cover more "tree space" consisting of 1000 random taxon addition sequence replicates using TBR, and limiting the maximum number of trees saved in each replicate to 100. All characters 

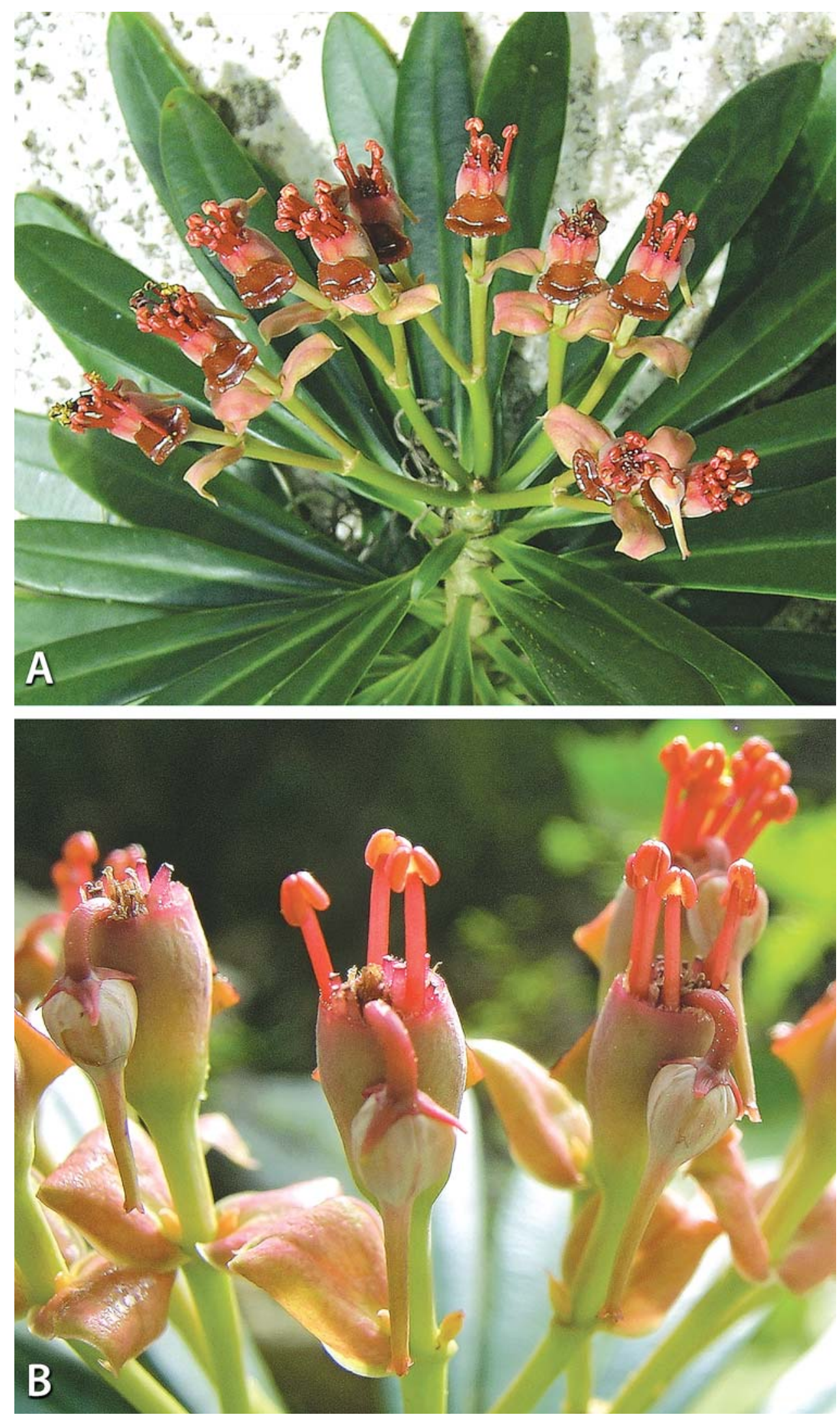

Fig. 1. Euphorbia umbelliformis: A, spirally arranged stem leaves clustered towards the branch tips; terminal, dichotomously branched cymes of cyathia; and cyathia with a single shield-shaped gland on the outer wall of the involucre; $\mathbf{B}$, cyathia with a recurved pedicel in fruit, a well-developed calyx-like structure at the base of the pistillate flower, and elongate, connate styles. Photographies by P.E. Berry in Guantánamo Province, Cuba, same plant as HAJB 81901. 
were weighted equally. Bootstrap percentages were obtained from 1000 bootstrap replicates of 100 random addition sequence replicates each, simple taxon addition (holding one tree at each step), TBR branch swapping, and the optimality criterion set to parsimony.

The best fitting likelihood model was selected from among the 56 models evaluated in Modeltest ver. 3.07 (Posada \& Crandall, 1998). The maximum likelihood heuristic searches were done starting with one of the most parsimonious trees and TBR branch swapping.

Incongruence between the ITS and $n d b F$ gene regions was evaluated using the incongruence length difference (ILD) test (Farris \& al., 1994), implemented as the partition homogeneity test in PAUP* ver. 4.0b10 (Swofford, 2002) using 100 partition homogeneity replicates of 10 random addition sequence heuristic parsimony searches with TBR branch-swapping.

\section{Results}

The ITS and $n d b F$ portions of the data set have aligned lengths of 739 and 1590 bases, and 446 (60\%) and $499(31 \%)$ parsimony-informative sites respectively. The incongruence length difference (ILD) test on the 47 taxon data set failed to reject $(P=0.13)$ the hypothesis of no meaningful conflict between the partitions indicating that the nuclear and chloroplast markers are not incongruent.

The initial MP analysis of the combined ITS and $n d b F$ data set produced 57 most parsimonious trees of 6525 steps each, with a consistency index (CI) of 0.335 and a retention index (RI) of 0.659 . The subsequent search employing 100 random addition sequence replicates did not recover any shorter trees, nor any with a novel topology. Both the hierarchical likelihood ratio tests (hLRTs) $(\alpha=0.01)$ and Aikaike Information Criterion (AIC), as implemented in Modeltest ver. 3.07 (Posada \& Crandall, 1998), found GTR+G+I to be the best-fitting model for the combined data. An ML search of the combined ITS and $n d b F$ data set, using this model, recovered a single tree (Fig. 2). The MP analyses did not recover any well-supported alternative topologies compared to the single $M L$ tree, which is compatible with the strict consensus tree of the $57 \mathrm{MP}$ trees. Therefore, the single ML tree with MP bootstrap percentages illustrated (Fig. 2) represents our preferred phylogenetic hypothesis, and the MP trees are not shown given that none of them vary substantially from the ML tree. Separate ML and MP analyses of ITS and $n d b F$ confirmed the results of the combined analyses and did not result in any alternative topologies; likewise, they are not presented here.

All five newly sampled taxa belong to a well-supported group together with the Caribbean endemic E. punicea (100\% bootstrap). Euphorbia gymnonota, a species endemic to the Bahamas, is recovered sister to Cubanthus umbelliformis. This monophyletic clade of endemic Antillean Euphorbia forms part of clade C in Steinmann and Porter (2002), and part of a New World assemblage that includes members of sections Adenorima (Raf.) G.L. Webster, Euphorbiastrum (Klotzsch \& Garcke) Boiss., Pteroneurae A. Berger, Portulacastrum Boiss., Stachydium Boiss., and the former genus Pedilanthus. Within this Antillean clade, there are two strongly supported subclades. The first contains the Cuban endemic species E. helenae, E. munizii, and E. podocarpifolia. The second subclade consists of E. cubensis, E. punicea, E. gymnono$t a$, and Cubanthus umbelliformis.

The ML analysis recovered the Mexican Euphorbia tanquabuete Sessé \& Moc., as sister to the "Cubanthus" clade, but this relationship has an extremely short branch length, and it was not recovered in our parsimony bootstrap analysis of the combined data, nor was it recovered in the MP analysis of Steinmann and Porter (2002). The Pedilanthus clade, which is represented in our study by two species, emerges on an unusually long branch in the same New World portion of Clade $\mathrm{C}$ as Cubanthus, but nested within other Central and South American taxa, rather than being directly sister to Cubanthus (see Fig. 2).

\section{Discussion}

Given that $C$ ubanthus represents a small clade nested well within Euphorbia, we conclude that it deserves the same fate as Euphorbia's other satellite genera, namely, a reduction to synonymy. In a morphologicalbased phylogenetic analysis of New World members of Euphorbiaceae subtribe Euphorbiinae (Park, 1996), Cubanthus was recovered as the earliest diverging lineage, sister to the remaining species of the subtribe. However, both the results presented here and those of Wurdack \& al. (2005), strongly contradict that analysis. No evidence of a close relationship with Pedilanthus was suggested by the morphological analysis, and morphological similarities between these groups, such as bilaterally symmetric cyathia and elongated united styles, appear to have arisen independently. These results are supported by the molecular analysis presented here (Fig. 2).

Although a thorough and uniform classification of Euphorbia remains to be achieved, Webster (1994) 


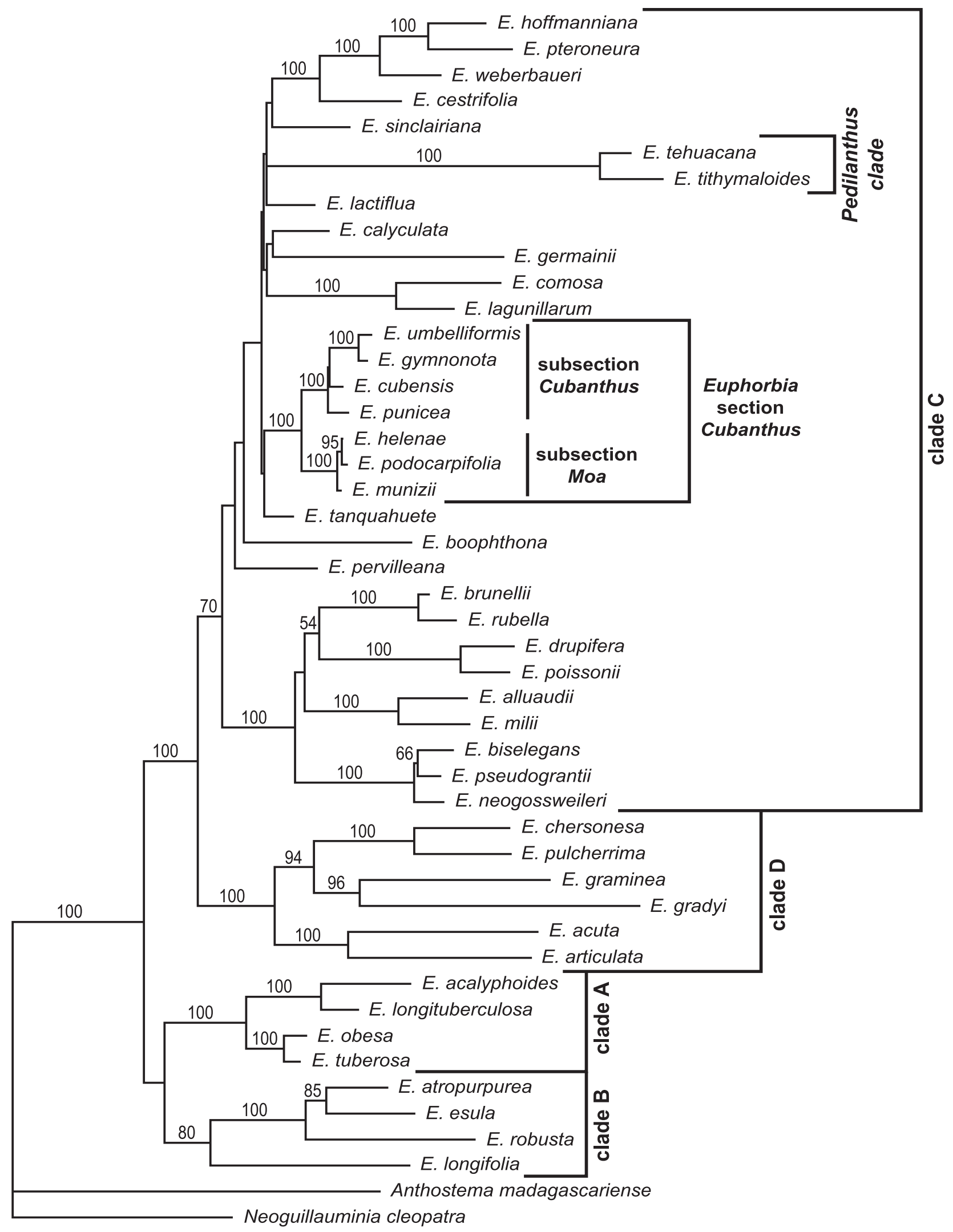

0.01 substitutions/site

Fig. 2. Maximum likelihood phylogram of the combined ITS and $n d h F$ analysis. MP bootstrap percentages of $50 \%$ or more are shown above the branches. Clades A through D follow Steinmann and Porter (2002). 
appears to have been correct that Cubanthus is best combined with his section Adenorima. The type of sect. Adenorima is Euphorbia punicea, a species demonstrated here to be closely related to Cubanthus umbelliformis. Thus, we propose treating Cubanthus as a section of Euphorbia and expanding it to include Euphorbia cubensis, E. gymnonota, E. punicea, E. helenae, E. munizii, and E. podocarpifolia. Given that Cubanthus was first proposed as a section of Pedilanthus in 1862, it has priority over Webster's sect. Adenorima, and we consequently relegate the latter to synonymy below. Following the modifications in classification proposed by Bruyns \& al. (2006), sect. Cubanthus belongs to the expanded subgenus Euphorbia. The section is characterized as follows: shrubs or small trees, monoecious, latex white, branches soft-wooded, flexible and somewhat fleshy; leaves spirally arranged, often clustered towards the end of the branches, stipules minute and glanduliform or apparently absent, caducous; lamina pinnnately veined, membranaceous to slightly coriaceous, lacking a well-defined petiole, entire; cyathia in terminal dichasia, relatively large; cyathophylls generally red; glands one to eight, situated on the rim of the involucre or on its outer wall, green, yellow or reddish, appendages lacking; ovaries and fruits smooth, glabrous, sometimes subtended by a three-lobed, calyx-like structure, styles united at least at the base, sometimes nearly their whole length, undivided or bifid; seeds ecarunculate.

We treat the two highly supported clades of sect. Cubanthus as subsections: subsect. Moa, comprising the entirely Cuban belenae-munizii-podocarpifolia clade, and subsect. Cubantbus, including the more widespread assemblage of E. punicea, E. cubensis, E. gymnonota, E. umbelliformis, and presumably the other two former members of Cubanthus (E. millspaughii and E. scutiformis - see below). Subsection Moa is entirely restricted to serpentine soils in and around Moa in Holguín Province of eastern Cuba, and the species are small trees or shrubs with small to medium sized, elliptic to oval leaves that are usually spaced regularly along the stems. In contrast to subsect. Cubanthus, the reproductive stems are terminated by a whorl of conspicuously bright red leaves that subtend the dichasia, and these are considerably different in shape from the lower stem leaves. Furthermore, all three species have showy red bracts subtending the cyathia, and the involucres themselves are red in these species, as are the ovary, the stamens, and the pedicels (Fig. 3). The five cyathial glands are yellow and are situated on the rim of the involucre, as is common in the genus. The styles are relatively short in this clade and are fused for about a third to half their length.

Subsection Cubanthus is similar to subsect. Moa in that all members are shrubs or small trees. However, they differ from subsect. Moa in having much larger, narrowly spathulate leaves that are more closely grouped towards the branch apices, and those subtending the dichasia are not conspicuously different from the lower leaves. Three of the four species sampled here in subsect. Cubanthus are unusual in having their involucral glands situated on the outer wall of the involucre, with the glands varying in number from one to eight. These same three species also have reddish bracts subtending the cyathia, although the coloring is less intense than that of subsect. Moa, and the ovaries themselves remain green. The Jamaican E. punicea has up to eight glands on the outer involucral wall (Fig. 4 a), the Bahamian E. gymnonota typically has five but sometimes as few as three (Fig. 4 c, d), and the Cuban and Hispaniolan E. umbelliformis and the other two former members of Cubanthus from Cuba all have one large shield-shaped gland on the outer involucral wall (Fig. 1 a). These species also share elongate styles (as long as the ovary) that are connate for nearly their whole length. Euphorbia umbelliformis has remarkably well developed calyx-like lobes subtending the ovary, but this condition is not diagnostic of the entire subsection, and other species, such as E. gymnonota, lack this feature. The "odd man out" in this group is E. cubensis, which has rather nondescript, entirely green cyathia, with no subtending colored bracts, and with five glands situated on the rim of the involucre (Fig. 4 b). It does share, however, the typical apically grouped, spathulate leaves present in the other members of this subsection. Although not included in this study, E. dussii Krug \& Urb., an endemic to the islands of Martinique and St. Lucia, probably also belongs in this subsection.

The molecular phylogeny presented here supports the hypothesis that section Cubanthus radiated entirely within the Antilles and the nearby Bahamian archipelago. A radiation out of mainland Central America or North or South America would have required multiple independent dispersals to the islands, along with extinction of related taxa on the mainland, in order to obtain the observed distribution of these closely related taxa. The main issue now to resolve in section Cubanthus is to better define its closest sister group, but this may be problematical given that the basal structure in the New World members of clade C is not well resolved or supported. In the ML analysis, Euphorbia tanquabuete is sister to sect. Cubanthus, but there is no bootstrap support for this. Euphorbia tan- 

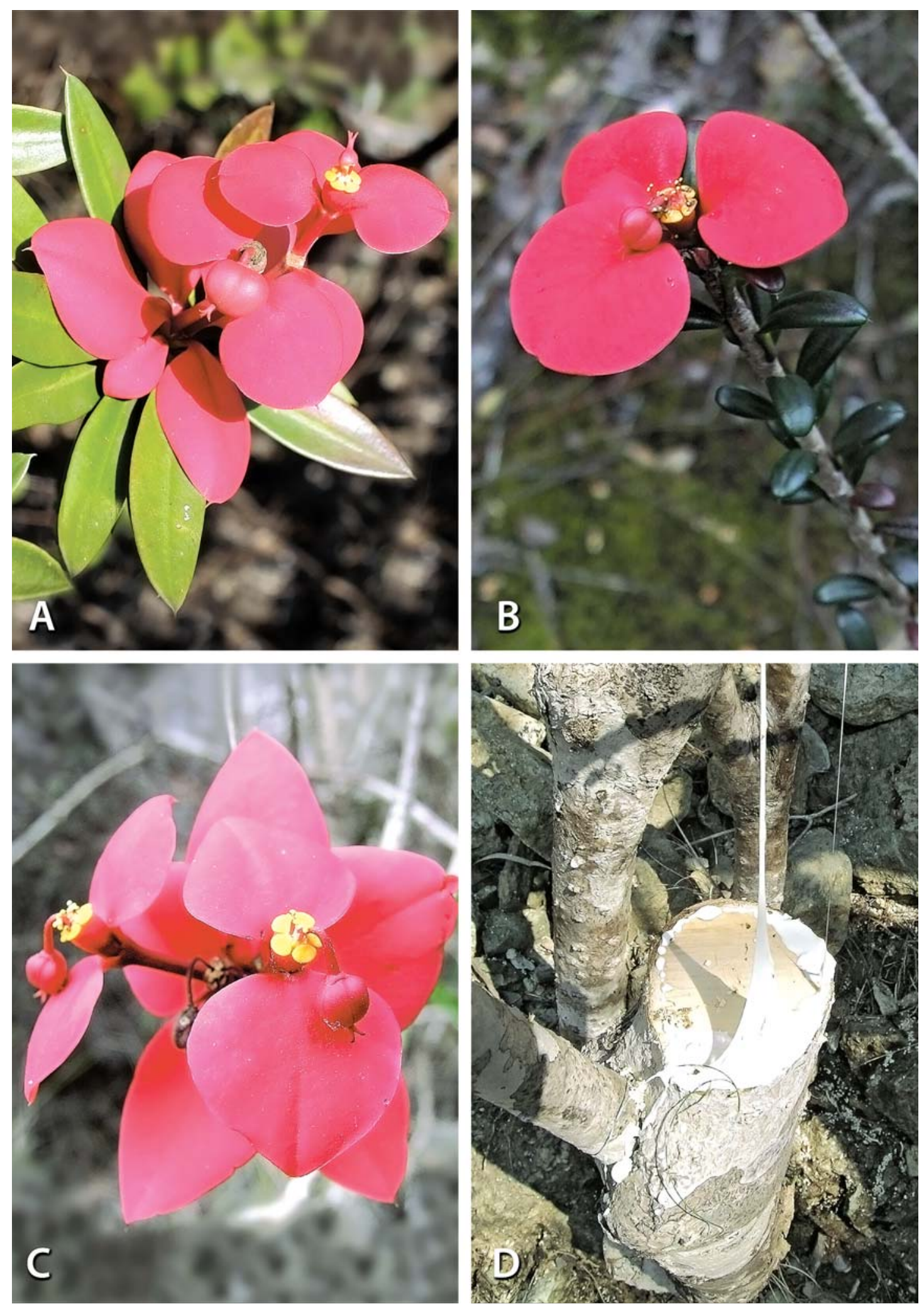

Fig. 3. A, Euphorbia helenae: Flowering branch showing the bright red bracteate leaves, the red cyathial involucre and gynoecium, and the short, partly fused styles. Photography by P.E. Berry in Holguín Province, Cuba, same plant as HAJB 81741. B, E. munizii: Flowering branch, showing close similarities in the inflorescence to $E$. helenae, but note marked difference in the leaves. Photography by P.E. Berry in Holguín Province, Cuba, same plant as HAJB 81796. C, D, E. podocarpifolia: C, flowering structures very similar to E. helenae and E. munizii. Leaves in this species are linear, however. Note the small calyx-like structure at the base of the ovary; D, sawed trunk of tree showing considerable girth $(25 \mathrm{~cm}$ diam.) and copious white latex. Photographies by P.E. Berry in Holguín Province, Cuba, same plant as HAJB 81712. 

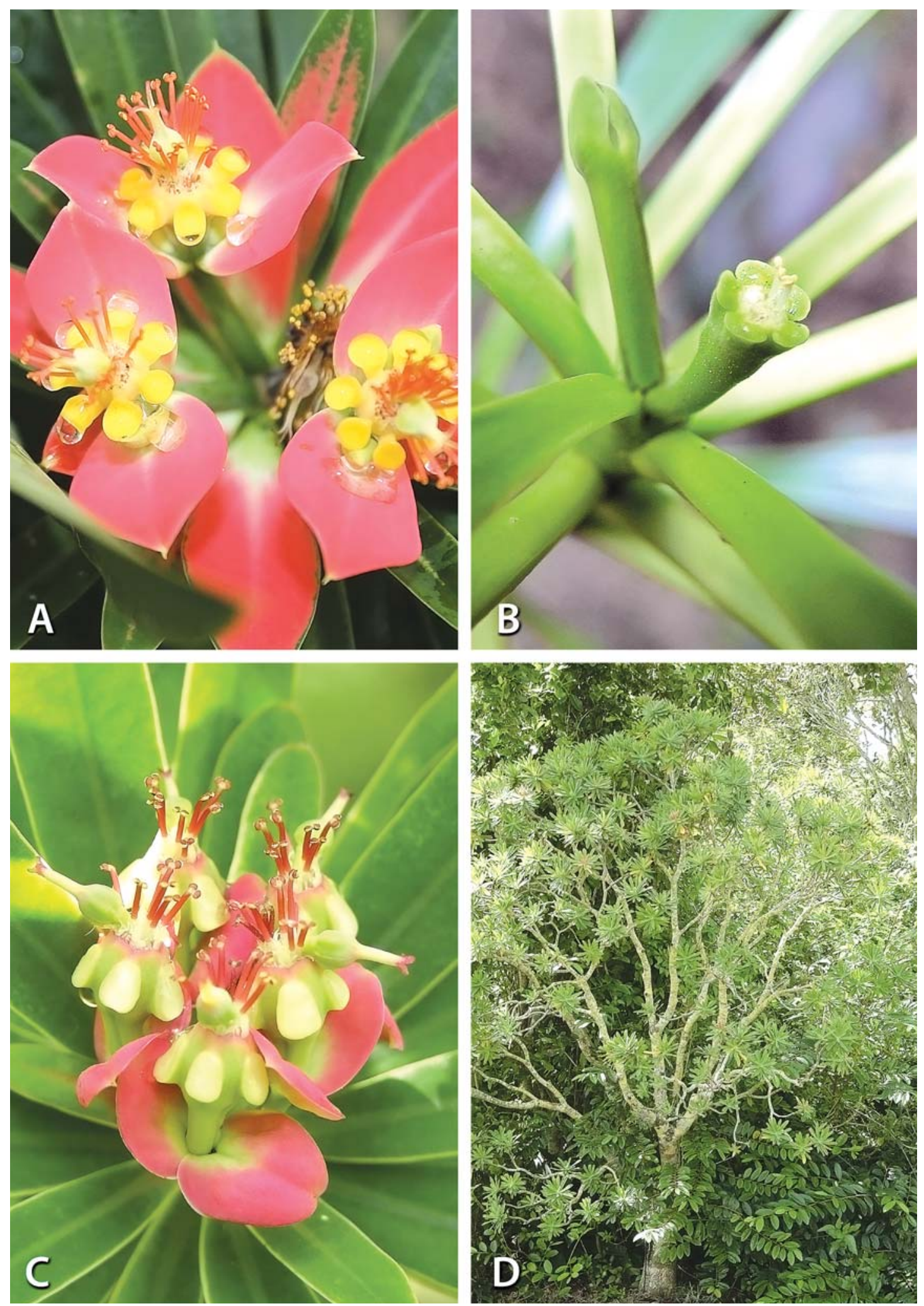

Fig. 4. A, Euphorbia punicea: Flowering stems showing red cyathophylls, greenish ovary and involucre, and seven to eight involucral glands. Photography by P.E. Berry at Paul Ecke Poinsettia Ranch, Encinitas, California, same plant as Berry \& Riina 7848 (MICH). B, E. cubensis: Rather nondescript terminal cyathium showing green, normally positioned cyathial glands and complete lack of any reddish coloration. Leaves are narrowly spathulate and clustered near the shoot apexes. Photography by P.E. Berry in Pinar del Rio Province, Cuba, same plant as HAJB 81971. C, D, E. gymnonota: C, note slight red coloration of cyatophylls, greenish involucre and ovary, and five nectaries on the outer involucral wall; $\mathbf{D}$, branched arborescent habit showing spathulate leaves grouped at branch tips characteristic of section Cubanthus. Photographies by L. Raz at Fairchild Tropical Botanical Garden, same plant as Raz 882. 

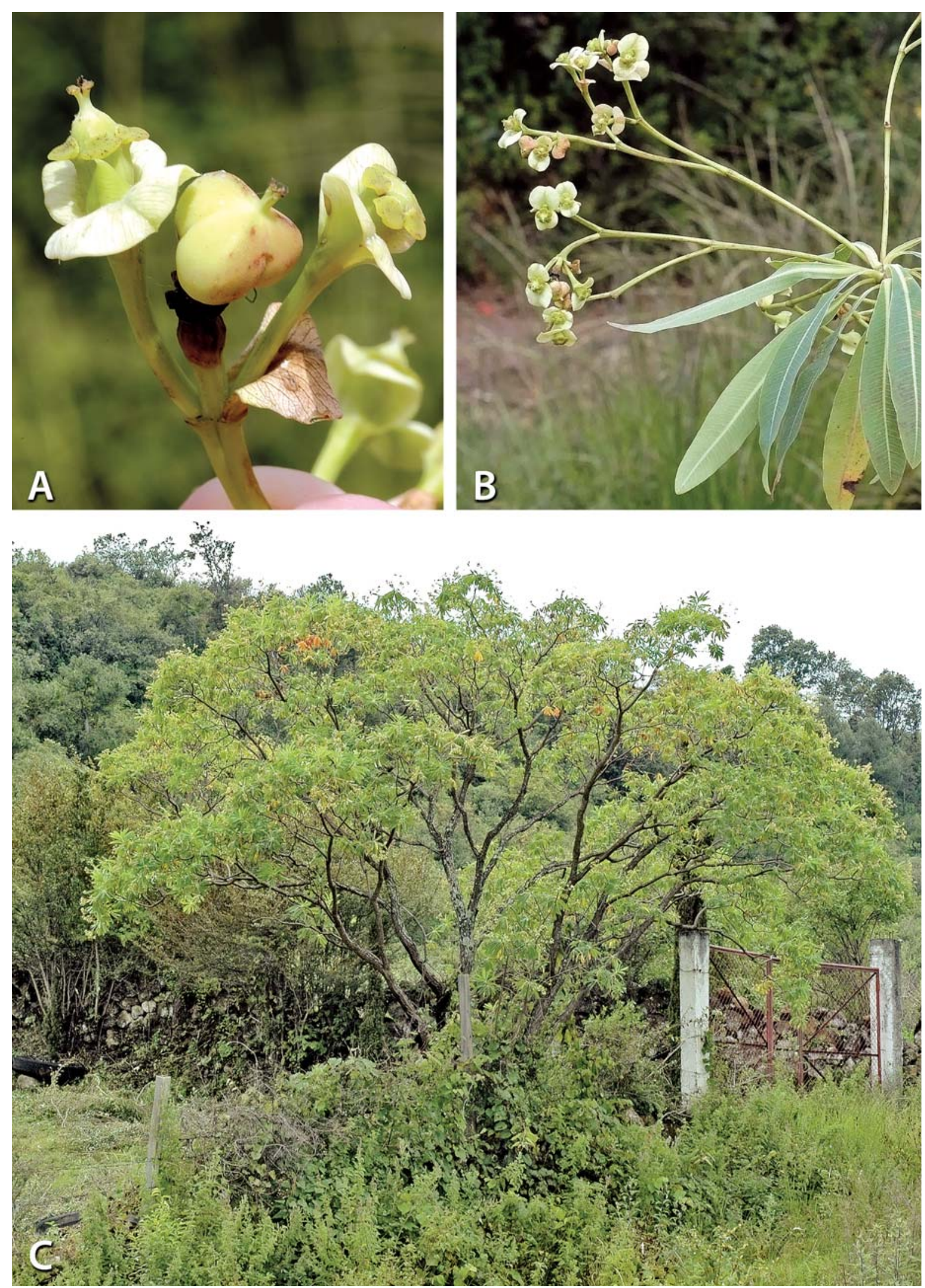

Fig. 5. Euphorbia calyculata: A, dichasium of cyathia showing the five involucral glands at the rim of the involucres, the whitish cyathophylls, and a young fruit; $\mathbf{B}$, terminal, dichasial arrangement of cyathia and spathulate leaves grouped at the stem apex, both characters found in members of section Cubanthus; C, well-branched arborescent habit. Photographies by V.W. Steinmann in Michoacán, Mexico, same plant as Steinmann \& Ramírez-Amezcua 5490 (IEB). 
quabuete differs from species of sect. Cubanthus by possessing exfoliating bark and bearing cyathia in short axillary dichasia. Morphologically, the species of sect. Cubanthus are most similar to the Mexican Euphorbia calyculata Kunth, a soft-wooded tree that similarly has the cyathia in dichotomously branched cymes at the ends of the stems and like members of subsection Cubanthus has relatively large leaves that are closely grouped towards the branch apices (Fig. 5). Euphorbia calyculata also has a calyx-like structure at the base of the female flower, a feature shared with some members of sect. Cubanthus, but very rare in Euphorbia as a whole.

\section{Taxonomic changes}

The names for Cubanthus when treated as Euphorbia are as follows:

Euphorbia sect. Cubanthus (Boiss.) V.W. Steinm. \& P.E. Berry, comb. nov. [Pedilanthus sect. Cubanthus Boiss. in DC., Prodr. 15(2): 7. 1862; Cubanthus (Boiss.) Millsp., Publ. Field Mus. Nat. Hist., Bot. Ser. 2: 371. 1913]. Type: Pedilanthus linearifolius Griseb. (= Euphorbia scutiformis V.W. Steinm. \& P.E. Berry).

Adenorima Raf., Fl. Tell. 4: 112. 1838 ('1836'); Euphorbia sect. Adenorima (Raf.) G.L. Webster, J. Arnold Arbor. 48: 407. 1967. Type: Adenorima punicea (Sw.) Raf. (= Euphorbia punicea Sw.).

Euphorbia sect. Cubanthus subsect. Moa V.W. Steinm. \& P.E. Berry, subsect. nov. Type: Euphorbia helenae Urb.
Arbores vel frutices. Folia ordinate disposita, parva vel media, elliptica vel ovalia. Bracteae atque involucra rubra. Glandulae 5, flavae, exappendiculatae.

This subsection also includes the closely related E. munizii and E. podocarpifolia.

Subsection Cubanthus includes E. cubensis, E. punicea, and E. gymnonota in addition to the following three former species of Cubanthus:

Euphorbia millspaughii V.W. Steinm. \& P.E. Berry, nom. nov. (Cubanthus brittonii [as brittoni] Millsp., Publ. Field Mus. Nat. Hist., Bot. Ser. 2: 372. 1913). A new name is required because of the prior existence of Euphorbia brittonii Millsp., Publ. Field Columbian Mus., Bot. Ser. 2: 159. 1906. The new specific epithet pays homage to Charles Frederick Millspaugh (18541923), plant collector and research botanist at the Field Museum in Chicago.

Euphorbia scutiformis V.W. Steinm. \& P.E. Berry, nom. nov. (Pedilanthus linearifolius Griseb., Mem. Amer. Acad. Arts ser. 2, 8: 161. 1861; Cubanthus linearifolius (Griseb.) Millsp., Publ. Field Mus. Nat. Hist., Bot. Ser. 2: 371. 1913). A new name is required because of the prior existence of Euphorbia linearifolia Roth, Nov. Sp. Pl. 224. 1821. The specific epithet scutiformis (shield-shaped) is given in reference to the unusual configuration of the two united involucral glands.

Euphorbia umbelliformis (Urb. \& Ekman) V.W. Steinm. \& P.E. Berry, comb. nov. [Cubanthus umbelliformis Urb. \& Ekman, Ark. Bot. 20A(15): 68. 1926].

Table 1. Voucher information and GenBank numbers for newly generated sequences of Euphorbia used in this paper. Voucher information and GenBank numbers for all other Euphorbia and outgroup sequence data are in Steinmann and Porter (2002).

\begin{tabular}{|c|c|c|c|}
\hline Taxon & Origin \& voucher & ITS GenBank accession & ndhF GenBank accession \\
\hline E. cubensis Boiss. & $\begin{array}{c}\text { Cuba, Cajálbana, HAJB } 81971 \\
\text { (HAJB, MICH) }\end{array}$ & EF653254 & EF653259 \\
\hline E. gymnonota Urb. & $\begin{array}{c}\text { ITS: Bahama Islands, } \\
\text { Correll \& Wasshausen } \\
46769 \text { (NY) } \\
\text { ndhF: Cultivated } \\
\text { (nat. Bahamas), } \\
\text { Raz } 882 \text { (FTG, MICH) }\end{array}$ & AF537507 & EF653260 \\
\hline E. helenae Urb. & $\begin{array}{c}\text { Cuba, Holguín, HAJB } 81741 \\
\text { (HAJB, MICH) }\end{array}$ & EF653255 & EF653261 \\
\hline E. munizii Borhidi & $\begin{array}{l}\text { Cuba, Holguín, HAJB } 81796 \\
\text { (HAJB, MICH) }\end{array}$ & EF653256 & EF653262 \\
\hline E. podocarpifolia Urb. & $\begin{array}{c}\text { Cuba, Holguín, HAJB } 81712 \\
\text { (HAJB, MICH) }\end{array}$ & EF653257 & EF653263 \\
\hline $\begin{array}{l}\text { E. umbelliformis (Urb. \& Ekman) } \\
\text { V.W. Steinm. \& P.E. Berry }\end{array}$ & $\begin{array}{c}\text { Cuba, Guantánamo, HAJB } 81901 \\
\text { (HAJB, MICH) }\end{array}$ & EF653253 & EF653258 \\
\hline
\end{tabular}




\section{Acknowledgements}

We gratefully acknowledge funding from the University of Wisconsin-Madison Latin American, Caribbean and Iberian Studies Program, a Vilas travel grant from the UW-Madison Graduate Student Collaborative, a Davis Fund grant from the UW-Madison Department of Botany, and an NSF Planetary Biodiversity Inventory grant (DEB-0616533). We are grateful to Lauren Raz of Fairchild Botanical Garden for collecting and photographing E. gymnonota, and we are indebted to the Jardín Botánico Nacional outside of La Habana for graciously assisting us with field collecting in Cuba. M. Laínz kindly revised the Latin diagnosis. Finally, we thank Geoff Levin and an anonymous reviewer for their helpful suggestions to improve an earlier version of the manuscript.

\section{References}

Bernal, R., Mora, F. \& Murillo, J. 2006. Euphorbia sinclairiana, an older name for the widespread Euphorbia elata. Caldasia 28: 217-220.

Boissier, E. 1862. Euphorbieae. In: De Candolle, A. (ed.), Prodromus Systematis Naturalis, part 15(2), pp. 3-188. Victor Masson $\&$ Fils, Paris.

Bruyns, P.V., Mapaya, R.J. \& Bruyns, T.H. 2006. A new subgeneric classification for Euphorbia (Euphorbiaceae) in southern Africa based on ITS and psbA-trnH sequence data. Taxon 55 : 397-420.

Dressler, R.L. 1957. The genus Pedilanthus (Euphorbiaceae). Contributions of the Gray Herbarium 182: 1-188.
Farris, J.S., Kallersjo, M., Kluge, A.G. \& Bult, C. 1994. Testing significance on incongruence. Cladistics 10:315-319.

Liogier, E.E. 1953. Dicotiledóneas: Malpighiaceae a Myrtaceae. In: Sauget, J.S. \& Liogier, E.E. (eds.), Flora de Cuba, vol. III. Museo de Historia Natural del Colegio La Salle. La Habana.

Millspaugh, C.F. 1913. The genera Pedilanthus and Cubanthus, and other American Euphorbiaceae. Publications of the Field Museum of Natural History, Botanical Series 2: 353-373.

Park, K.-R. 1996. Phylogeny of the New World subtribe Euphorbiinae (Euphorbiaceae). Korean Journal of Plant Taxonomy 26: 235-256.

Posada, D. \& Crandall, K.A. 1998. MODELTEST: testing the model of DNA substitution. Bioinformatics 14: 817-818.

Steinmann, V.W. \& Porter, J.M. 2002. Phylogenetic relationships in Euphorbieae (Euphorbiaceae) based on ITS and ndhF sequence data. Annals of the Missouri Botanical Garden 89: 453. 490.

Swofford, D.L. 2002. PAUP*: Phylogenetic Analysis Using Parsimony ("and Other Methods). Version 4.0610. Sinauer Associates, Sunderland, MA.

Webster, G.L. 1994. Synopsis of the genera and suprageneric taxa of Euphorbiaceae. Annals of the Missouri Botanical Garden 81: 33-144.

Wurdack, K.J., Hoffmann, P. \& Chase. M.W. 2005. Molecular phylogenetic analysis of uniovulate Euphorbiaceae (Euphorbiaceae sensu stricto) using plastid rbcL and trnL-F sequences. American Journal of Botany 92: 1397-1420.

Associate Editor: C. Aedo Received: 13-VI-2007 Accepted: 29-VIII-2007 